InOdia $\quad \begin{aligned} & \text { InMedia } \\ & \text { The French Journal of Media Studies }\end{aligned}$

7.1. $\mid 2018$

Visualizing Consumer Culture

\title{
Visualising Commodity, Consuming Visual Commodities: the Shakespearean Stage
}

\section{Stephanie Mercier}

\section{(2) OpenEdition}

12 Journals

\section{Electronic version}

URL: http://journals.openedition.org/inmedia/1276

DOI: 10.4000/inmedia.1276

ISSN: 2259-4728

\section{Publisher}

Center for Research on the English-Speaking World (CREW)

\section{Electronic reference}

Stephanie Mercier, « Visualising Commodity, Consuming Visual Commodities: the Shakespearean Stage », InMedia [Online], 7.1. | 2018, Online since 20 December 2018, connection on 08 September 2020. URL : http://journals.openedition.org/inmedia/1276 ; DOI : https://doi.org/10.4000/inmedia. 1276

This text was automatically generated on 8 September 2020

(C) InMedia 


\title{
Visualising Commodity, Consuming Visual Commodities: the Shakespearean Stage
}

\author{
Stephanie Mercier
}

\section{Introduction}

FALSTAFF I bought him in Paul's, and he'll buy me a horse in Smithfield. An I could get me but a wife in the stews, I were manned, horsed, and wived. (2 Henry IV, 1.2.44-46)

1 Commodities for sale could be found everywhere in early modern London but exchange goods were not limited to concrete marketplace items. Falstaff's tongue-in-cheek consumerist tour of its low life areas allows Shakespeare's audiences the experience of the purchase of animals in Smithfield, serving men looking for employment in St. Paul's and prostitutes in the Stews, so called because of the frequent use of public hotair bath-houses, or stews, for dissolute purposes. ${ }^{1}$ Shakespeare's language thus presents people as exchange goods in certain particular cases and suggests the early modern mindset could place animals, humans and merchandise on an undifferentiated par for value. Moreover, Falstaff's allusion to real-life markets such as the "stews" and "Smithfield" on a stage establishes a commercial network that links up the marketplace and the theatre. As a way of thinking beyond categories of victimisation and objectification, however, Shakespeare's words and their performance also refuse to categorise and challenge a division of society according to essentially patriarchal market interests. Instead they establish the centrality of gender and especially female agency in brokering societal relations. As such, Shakespeare's theatre defies static concepts: as female characters were performed by male actors identity and gender dissolve through staged experience. Further, as performance was also a commodity bought by spectators, playgoers of all degrees could, at least for the length of a performance, become consumers on their own terms. Jean E. Howard has remarked how modern theatre was both the "symbol of changing social conditions and practices" 
controlled by the power mechanism of society but also a commodity, "which the public paid money to see and over which, consequently, they exercised a certain degree of control". ${ }^{2}$ If even the lowliest "harlots", "strumpets", "punks" or "whores" (all of which can be found in Shakespeare) could consume the visual commodities of plays, perhaps other audience members might position themselves as "consumers, critics, spectators" 3 despite Falstaff's claims.

2 I thus examine commodity on Shakespeare's stage, in particular the enlightening representations of women as prostitutes, the lowest form of commodity, in the tavern and brothel scenes in 1 and 2 Henry IV (1596-1597, 1597-1598) and Pericles (1608) that show women to be subservient, sold for money and yet showcased to expose the illusion of this control. More particularly, I turn to how early modern England experienced prostitution, a topic that has previously been addressed from the viewpoint of male abuse of power. By focusing on commodity, within the framework of London's Southwark area and its performance-related context, however, we see how, in theatre, commodity is most importantly the body of the actor, without which the words in Shakespeare's text cannot be performed. By extension, the play is a commodity mirroring and serving some spectators, who were themselves considered to be embodied objects: the prostitutes in the audience come to ply their trade or simply watch a play. Thus, in some instances, commodity can be a theatrical tool to undermine the deprivation of agency and maintain dignity despite condescending or moralistic depictions of status, whether actor or whore. As such, the prostitute is no longer a symbol of isolation. ${ }^{4}$ That female characters were played by male actors at a time when the acting profession was itself considered by some to be a form of prostitution ${ }^{5}$ further justifies the focus on theatre to address the issue. Besides, if the Jacobean City Comedies depict prostitutes in their investigation of mass urban living and culture, they do so exclusively from a perspective of the working people of the city. ${ }^{6}$ As Shakespeare's plays cover such a wide range of societal issues and classes, they provide a broader point of reference with which to examine early modern prostitution and the theatre, especially as Shakespeare was a theatre proprietor himself. Shakespeare's work is thus particularly valuable to an original contribution to the topic.

3 Admittedly, the subject is a well-documented one, yet it is nonetheless worthwhile expanding on contemporary research that addresses separate issues of Shakespeare and early modern poverty and vagrancy, ${ }^{7}$ female prostitution, ${ }^{8}$ or hired men-whether in husbandry or as actors ${ }^{9}$-because, as whores were an increasingly visible part of Shakespeare's London and stage, ${ }^{10}$ they too engage in cross-cultural debates on commodity for audiences. Traditionally marginalised female characters such as Mistress Quickly and Doll Tearsheet can thus be regarded as examples, not of ostracism but of (micro)resistance to deprivation of agency by their male counterparts. Gamini Salgado notes, in his publication on popular history, how the playhouse was a "favourite prelude to the brothel, either as a place of assignation or as an appetizer for later pleasures". ${ }^{11}$ Inversely, the brothel could act as a prologue to a performance of early modern consumer culture that defies traditional gender and identity boundaries. 


\section{The changing nature of commodities in early modern England}

4 The first notable aspect about female commodities in early modern England was their changing nature. I thus begin within what the early modern pamphleteer Robert Greene, in A notable discouery of coosenage (1592), terms as the "Trugging place", his euphemism for the whorehouse, because "trugge" was his synonym for whore. ${ }^{12}$ Eric Partridge, in A Dictionary of the Underworld, helpfully explains how "trug" later merged into "trull" and "truck", "a word for exchange", ${ }^{13}$ perhaps anticipating how whores possessed the power to reinvent themselves in defiance of an ideological structure that saw them as passive and subservient objects. If Greene explicitly designates whores as merchandise dispossessed of power-“The Whore: a Commodity"14-sex workers' important role in early modern England meant that they could also serve as market intermediaries that bound people together within a community of shared desire. The common prostitute was an exchange object to be randomly sold for possession and subsequently enjoyed by cash buyers, and yet contemporaneous literature such as Greene's also recognises the dangers to societal order of the seductive power of even the cheapest female goods for sale:

Ah gentlemen, merchants, yeomen and farmers, let this to you all, and to every degree else, be a caveat to warn you from lust, that your inordinate desire be not a means to impoverish your purses, discredit your good names, condemn your souls, [...] Some fond men are so far in with these detestable trugs, that they consume what they have upon them, and find nothing but a Neapolitan favor for their labor. 15

5 Women were considered commodities for male consumption whose value diminished after they were "used" 16 but a prostitute, because she appropriated single and married men's time ("inordinate desire"), reputation ("good name", "souls"), money ("impoverish your purses"), and health altogether-since "Neapolitan favor" was a synonym for syphilis ${ }^{17}$-was also a disturbing element for the family and its budget. ${ }^{18}$ Prostitution did not always reduce women to the status of generic objects despite attempts towards their general standardisation by early modern authorities. It follows that prostitutes commanded the potential to restructure social norms more than they have often been given credit for and thus had influence on the whole of society because they were an important part of early modern culture.

Indeed, Shakespeare reminds us that if Falstaff's real-life fifteenth-century counterparts wanted to pay to have sex with a woman in the capital they would have known where to find one. Successive royal proclamations had organised prostitution in zones. Henry II, for instance, had localised brothels by an 1162 ordinance in Southwark; prostitution fell under the jurisdiction of the Bishop of Winchester and was supervised by church authorities that tolerated the practice as a "necessary evil" ${ }^{19}$ since it was a preferable practice to the rape of virtuous wives and daughters. ${ }^{20}$ If prostitution was authorised within the bustling horse and cattle market area in Cock Lane, Smithfield, by the London enactment of 1393, there was still a strong urge to contain the phenomenon. ${ }^{21}$ Salgado observes how "all brothels had to be painted white and to carry a distinctive sign"22 to mark prostitution as a stable and identifiable commerce.

7 By the Renaissance, however, a mechanical rise in the number of prostitutes accompanied London's population that increased from an estimated 50,000 in 1530 to 
about 225,000 in 1605-approximately 75,000 Londoners lived in the City and 115,000 lived in the lands known as the Liberties, so called because they were outside the city's restrictive regulatory zones. ${ }^{23}$ Socio-economic factors explaining this rise included a large number of beggars who could no longer be cared for after the 1535-1540 dissolution of the monasteries in the wake of Henry VIII's break from Rome. ${ }^{24}$ The move to less labour consumptive farming methods, such as sheep rearing instead of corn growing, also led to the depopulation of the countryside. ${ }^{25}$ Monetary changes involving currency debasement and recoinage in an attempt to adjust diminishing royal income to increased expenditure resulted in inflationary pressure. The unsteady commercial structure was impossible for many to adjust to without urban migration. ${ }^{26}$ The arrangement between the Diocese and the commodities of Southwark collapsed because the sheer number of prostitutes meant that attempts to market women as identifiable commodities was no longer possible.

8 The prostitute, a commonplace merchandise essentially destined for male satisfaction with a recognised submissive role, thus became feared as a destabilising threat to societal order. This was initially because an increasing dread of syphilis developed along with the number of London's whores. John Stow's A Survay of London, records how eighteen licensed bordellos of Southwark well known "for the repaire of incontinent men to the like women" ${ }^{27}$ were thus closed for health reasons as early as 1506 and only twelve re-opened, ${ }^{28}$ which had the effect of "scattering the [remaining] prostitutes about London" 29 and worsening the impression of chaos. Secondly, the stricter moral religious fervour of the 1520s Reformation also meant a practice the Catholic Church had formerly licensed was now increasingly prohibited ${ }^{30}$ and the abolition of all licensed brothels in London eventually came with Henry VIII's 1546 proclamation. ${ }^{31}$ Instead of resolving the problem, however, the legislation only further disseminated prostitution. Robert Crowley remarks in 1550 that whores no longer permitted to ply their trade in brothels simply moved into taverns for security: "The bawdies of the stues / be turned all out / But some think they inhabit, / all England throughout / In taverns and tiplyng houses, / many might be found". ${ }^{32}$ The end of regulated Southwark brothels made supervision increasingly difficult; ${ }^{33}$ the result was that prostitution, because it was now no longer under control, could no longer be contained. Faramerz Dbhoiwala remarks how the end of licensed brothels had an overall effect of confusing the boundaries between waged and unwaged sexual activities. ${ }^{34}$ Practices then considered reprehensible, such as adultery, fornication, extramarital cohabitation or mistress keeping became harder to distinguish from prostitution. The outcome was socio-economic confusion that involved both the body and the budget.

9 As a result, prostitutes changed their very nature because they now participated in tavern activities traditionally held as masculine. Opinion was thus directed towards whores as unnaturally mannish, which further gave the impression of a dangerous empowerment. Thomas Thomas, in his 1587 dictionary, records this virility, further defying Greene's claims of the whore as a simple commodity: "Vǐrōsus, a, um, à Vir, Lucil, Desirous of or lusting after man, full of manly force, valiant as a man. Virosa mulier, Lucill. A stewed or arrant whore". ${ }^{35}$ The effect produced was that prostitutes, once accepted for their stable societal function as remunerated sexual outlets, now shared a conflated space in the collective imaginary with disorderly and dangerous men. Gilbert Walker, in Diceplay (1552), for example, pinions whores with tricksters set upon cheating the honest man of his hard-earned money. Scams included "crossbiting", where an unwitting client would be enticed into a tavern for a pint of wine only to find 
himself aggressed by the accomplice for attempting to corrupt an innocent woman and "only too glad to escape the bullying crossbiter by payment of forty shillings". ${ }^{36}$ George Whetstone, in A Mirror for Magistrates (1584), reminds readers of how "a plain minded man using these deceitful houses, is an assured prey for all sorts of shifters". ${ }^{37}$ The physical space of the whore's body became linked to general misdeeds. The prohibition of prostitution had destroyed one of the power structures that underpinned early modern society and its collective order. Whetstone, for instance, confirms the disintegration by putting gambling or buying drinks in a public house on a level with prostitution:

The man that is enticed to be a Dicer, of his own accord will be a Whoremaster: [...] Gods blood, let's go, straight he cryeth, and with more haste, then good speed, they go to some blind brothel-house where [...] for a bottle or two of wine, the embracement of a painted Harlot, and the French Pockes for a reckoning, the Punie payeth forty shillings. ${ }^{38}$

No wonder the ongoing early modern perspective on women as commodity was ambivalent. The redefinition of prostitution had caused the whore to be victimised or stigmatised-by her trade, by pamphleteers, or by laws attempting to regulate her profession-at the same time she remained a redoubtable physical and financial force to be reckoned with. Moreover, as Andrew Gurr notes, in documents such as William Harrison's "Description" of England, in introduction to Holinshed's Chronicles (1577), "the only women who were acknowledged to be self-employed were whores". ${ }^{39}$ This is particularly remarkable fact in a society where women were held to be dependent on their fathers or husbands. It further implies that prostitutes commanded the potential to transfer, perturb, and shape social norms more than they have often been given credit for because they were mediators on individual and collective levels.

Similarly, the Shakespearean stage, because of its mass audience ${ }^{40}$ and provision of a cross-class entertainment, ${ }^{41}$ had a wide-reaching cultural influence. More significantly still, the early modern stage had the advantage of a certain liberty of performance, meaning that Shakespeare, through his characters, could express points of view that were not normally aired. The changing nature of prostitution appears to have influenced the entire structure of early modern society. The prostitute's once recognisable position as a simple sexual commodity was destabilised. The end of regulated prostitution resulted, moreover, in a disintegration of patriarchal power and a certain amount of female empowerment. The new societal paradigm was made visible in Shakespeare's theatre, where the shift in conceptions was represented. In fact, a unilateral interpretation of prostitutes as simple exchange goods fails to consider several instances where we can see female self-expression overcome male command. Finally, because there was also a distortion of gender relationships in early modern theatre with men playing women, we must also take into account the possibility of alternative perspectives on men traditionally considered as commodity themselves.

\section{Commodities and performance}

HOSTESS QUICKLY O Jesu, he doth it as like one of these harlotry players as ever I see!

(1 Henry IV, 2.5.361)

When praising what was probably William Kemp's acting ${ }^{42}$ as Falstaff performing Hal's father during a parody of a father and son exchange in the Boar's Head tavern, Hostess Quickly uses the adjective "harlotry" in an embedded reference to the early modern 
acting profession. In so doing, she points to a whole range of market exchange systems and financial compensation inspired by whoredom such as acting. Her lines make us think of the geographical proximity, or even the direct implantation, of whores in the theatres bordering London but also of polemicists' criticisms of theatre as prostitution. Joseph Lenz notes that the analogy between players and whores was one that had been recognised since Plato's Republic because of the powerful seductive potential theatre had to subvert man's reason..$^{43}$ As Margareta de Grazia remarks, therefore, theatre is an ideal framework for visualising and understanding early modern consumer culture, where "value is misrepresented as a relation between objects", since it is a place of double convertibility: a place where actors are transformed into other characters and where money is transformed into spectacle. ${ }^{44}$ Furthermore, London's independent theatre industry emerged at the same time as prostitutes came out of its brothels and in the same places. It began with the Red Lion theatre in 1567 and the Theatre in 1576; both were built to the north of the city, as was the Curtain, in 1577; some companies still had to operate under the protection of a nobleman's or even Royal patronage in response to legislation that punished actors as prohibited vagrant beggars in the "Act for the Punishment of Vagabonds" (1572).

13 Then the Bankside theatres to the south of the capital were built: the Rose in 1587, the Swan in 1595, and the Globe in 1599. The latter was one of a group of five theatres, the others being the Fortune, to the north, in 1600 , to the east, the Boar's Head (formerly a tavern but converted into a theatre after the ban by authorities of theatrical performances in drinking places) in 1601, to the north-west, the Red Bull in 1604, and, to the south, the Hope, in 1614, which had the dual function of a theatre and a place of bear baiting. The first theatres gradually began to attract a crowd of spectators away from of the city of London towards the Liberties.

14 As was the case for prostitution, after a period of theatre being tolerated or even encouraged by those in power (such as the mystery play cycles performed during Catholic festivals) there came a strong legislative urge to limit it. This was again ostensibly for reasons of public health, as Lenz remarks: "Throughout the 1580s, the Lord Mayor repeatedly petitioned Elizabeth's government to discourage public plays as a means of curbing the danger of infection" 45 and plague epidemics also caused bans on playing. ${ }^{46}$ Over the period the dread of infection moved from "physical to moral corruption", ${ }^{47}$ however, with authorities fearing that, by attracting the masses away from church, theatre would destabilise and corrupt social order. The new theatres were thus contained socially, such as when one hundred and forty local residents petitioned to oppose the reconstruction of the Theatre; this was in the wealthy inner London Blackfriars district, when the lease for the land it was originally built upon ran out in $1597 .{ }^{48}$ Early modern theatre, like prostitution, also had to survive in difficult economic conditions caused by a rising population, the farming restrictions of enclosures and seven successive poor harvests. ${ }^{49}$ London's emerging sex and show businesses were therefore also economically devalued because they had to vie for trade in an increasingly competitive context and offer their commodities to a wide spectrum of spectators-described by Andrew Gurr as a "homogeneous, all-inclusive social range from gallants to grooms and from citizen's wives to whores". ${ }^{50}$

15 Logically, when whores went free-lance, as well as taverns, they also haunted other places of "public amusement such as the Bear Garden and the Globe, Rose, Hope, and Swan playhouses", ${ }^{51}$ either for their own pleasure or to ply their custom. Further, there 
was also a close relationship between the early modern stage and prostitution because theatre owners were also often brothel proprietors. These included the notorious impresario, Philip Henslowe (c. 1550-1616), who acquired the lease for the Little Rose, an "inn" in Southwark (one of the original Bankside stews) in 1585. Two years later, the partnership agreement for a theatre of the same name was signed, "to which the Little Rose lent its grounds, its name and, evidently its reputation". ${ }^{52}$ The Rose, where 1 Henry IV was first performed in 1596-1597, thus made material a mechanism of commodity in three ways: spectators paid for visual commodities of plays, they visualised prostitutes as commodities in them, and may have consumed the services of sex workers in the audience.

Philip Henslowe, like a pimp controlling his prostitutes, held players to their contract by keeping them perpetually in debt $^{53}$ and was, moreover, singled out, in the 1615 Articles of Oppression, for "having appropriated funds, stock and playbooks [or] binding hired men in his own name"; $; 4$ performing and prostitution, or simply visualising prostitution in performance inescapably conjured up the idea of commodity. Unsurprisingly, Puritan sources made a pejorative assimilation of the play and the whorehouse. Phillip Stubbes records, for instance, how audiences were corrupted by the "wanton gestures and bawdy speeches" witnessed in plays..$^{55}$ If Stubbes' was biased criticism, his records nonetheless provide evidence of how theatre could be perceived "through prostitution seeking eyes because the eyes, quite naturally and reflexively, seek prostitution. That is, they are attracted by, submit to, and enjoy visual stimulation". ${ }^{56}$ As women characters were generally played by apprentice male actors, theatre was "caught in a double bind" ${ }^{77}$ because of its visual display of men for counterfeit erotic stimulation and because this duplicity of pretence was also marketed for profit. Acting under contract could indeed be conflated with prostitution, either male or female, thanks to the "idea that male bodies were implicitly (or even explicitly) being objectified, just as women's bodies were, and that this happening precisely through the body of the boy actor". ${ }^{58}$

In response to a general dispossession of power, however, a consortium in which James Burbage's two sons, Richard and Cuthbert, owned fifty percent of the company and William Shakespeare, Augustine Phillips, Thomas Pope, John Hemmings and William Hemp the other fifty Percent (ten percent each), built the Globe. The theatre was thus owned by the actors and members of the Lord Chamberlain's troupe (with the exception of Cuthbert Burbage). The shareholders held full ownership of the building; the non-shareholders of the company were liable for all production costs, including their own wages, in exchange for the use of the theatre. Although the collective theatre ownership model was in its infancy at the end of the sixteenth century, the cooperative enterprise was recognised by the State and its growing activities consolidated and covered costs as a stable and successful enterprise. ${ }^{59}$ The new notions became part of the economic landscape to the point where actors who were not yet associated with the companies would come to demand their share; a petition called the "Sharers' Papers" in 1635, was written by Robert Benfield, Elliard Swanston and Thomas Pollard, who were already shareholders in the King's Players company but who wanted part of the profits another group of actor proprietors had divided among themselves. They asked for their money so that "the petitioners [...] might reap some better fruit of their labours than hitherto they have done, and be encouraged to proceed therein with cheerfulness". ${ }^{60}$ Such examples oppose fixed categorisations of people as objects. Indeed, just over forty years after the creation of what Andrew Gurr, following Richard 
Dutton, calls the "duopoly" of the Lord Chamberlain's and the Lord Admiral's Men in 1594, where playhouses were licensed for them in the suburbs with a simultaneous obligation to entertain the Queen and after a ban of players' free use of London's inns, ${ }^{61}$ actors had overcome the connotation of commodity and claimed control under their own conditions.

In this account of literature on early modern prostitution and theatre, we have seen how the stage and sex businesses were not just parallel but actually overlapped. Actors and sex workers were officially contained in the same places and were bound by restrictive legislation that linked them, both morally, in the collective imagination, and in terms of contemporaneous commerce, or fact. Early modern society encouraged a network of legal contracts and cultural boundaries to constrain individual freedom yet, contrary to expectations and no doubt to the great displeasure of the city fathers and its Puritans, prostitutes and players could also testify to a certain degree of social dignity and financial independence as legislation also created a possibility for cooperation and a certain collective well-being. As a factor of stimulation and social emulation, commodity could have the effect of making another voice heard-that of agency, which was reclaimed by those who were traditionally objectified. The ability to acknowledge and adapt to such new market systems was paramount. Shakespeare's staging of male players as commodities in 1 and 2 Henry IV and Pericles can thus be seen as giving voice and agency to even the least considered exchange goods and offer a new and challenging contribution to our understanding of early modern gender relationships.

\section{According agency to staged commodities}

19 The Oxford Companion to Shakespeare observes that nearly all of Shakespeare's plays mention prostitution, though no more than five portray it explicitly and only two, 2 Henry IV and Pericles, focus on women as sexual objects for sale within the context of a brothel. ${ }^{62}$ As the first plays have been identified as the future Henry V's "coming of age story", ${ }^{63}$ and Pericles as a "shift from medieval to early modern conceptions of female transgression", ${ }^{64}$ the two plays could quite plausibly reveal other forms of conversion, such as characters giving the impression of changing from one form to another or the play's text and performance persuading audiences to change their perceptions of characters. Within brothel scenes this entails the consideration of a transfer of power from subject to object, in an inversion of the early modern hierarchy of self, presided by God, and then men, to whom women were subordinate. Francis Grose, for example, defines commodity as a "woman's commodity: the private parts of a modest woman, and the public parts of a prostitute" 65 yet in these plays there is a movement of signifying systems that contests notions of women and their performers as subsumed into the status of generic objects and accords them agency instead.

20 Mistress Nell Quickly, the hostess of the Boar's Head tavern, is an embodiment of this transfer of power. Helge Kökeritz posits that her name would have been pronounced "quick lie" 66 and she is indeed adept at rapidly switching from one position to another: she is a tavern bawd in 1 and 2 Henry IV, wife to Pistol in Henry V (1599) and one of Doctor Caius's domestic servants and arbitrator for Mistresses Ford and Page in The Merry Wives of Windsor (1599), thus taking up functions and going places whores were not supposed to. Her challenge to authority upon her person also includes movement 
from a consumable object to that of provider. In 1 Henry IV she states: "Thou or any man knows where to have me" (3.3.117-18), mingling comedy and seriousness with the wordplay on "know" in its carnal sense, yet she also exhibits the capacity to withhold her sexual services ("you do not know me"), when she challenges Falstaff for not paying his debts for other everyday consumer objects:

HOSTESS QUICKLY No, Sir John, you do not know me, Sir John; I know you, Sir John.

You owe me money, [...] I bought you a dozen of shirts to your back. [...] You owe money here besides, Sir John: for your diet and by-drinkings, and money lent you, four-and twenty pound. (1 Henry IV, 3.3.57-65)

21 The scene's tavern setting, moreover, underscores the equivocal characteristics of prostitution, where authorities were intent on preserving the outward morality of male customers despite the dissolute commerce of women. Quickly is sexually exploited by Falstaff in the same way he exploits her generosity with regards to clothes or food; she is shown to be a victim in both cases and neither obtains recompense nor respect for her pains. Her staged words encourage acknowledgment of unfair treatment of early modern treatment women; the staging of Falstaff's misuse of power triggers a movement of thought towards the significance of whores from simple objects of male pleasure towards consumers ("I bought you") or contributors ("you owe me money") themselves, especially as "know" rhymes with "owe" to suggest that Falstaff should acknowledge Quickly as a person as well as pay her for her services as a prostitute. Performance of the character of Quickly clearly reinstates the right to self-expression as well as establishing the centrality of gender issues rather than simply marketorientated ones in this instance.

In 2 Henry IV Quickly continues to assume a position of feminine self rather than simply a commodity to be exchanged between the male customers who are willing to pay for her; she attempts to have Falstaff arrested for his debts and dishonest marriage proposal to her and hence claims the position of subject over a knight far above her in degree. If it is Quickly who is arrested in act 5, scene 4 (she is scapegoated for the physical violence that caused the death of man in a crossbiting incident) the parish officers' callous promise of physical punishment for another's misdemeanours amplifies awareness of Hostess Quickly's attempts to impose her own distinctiveness despite everything. Moreover, dramatically, the character is shown to be more than a negative stereotype because she is "given the job of revealing Falstaff's death in act 2, scene 3 of Henry $V$ so her importance in telling Falstaff's tale is considerable" ${ }^{67}$ Indeed, the announcement of the demise of one of the Henriad's most popular figures is performed from not only a female but from a prostitute's perspective to suggest that Shakespeare's, if not a resolutely feminist theatre, can be said to hold up a mirror to the world from a female standpoint at least from time to time.

Inversely, Falstaff's death is anticipated by Prince Hal's repudiation of his former tavern companion. As he attains the throne in 2 Henry IV, he too uses the lexis of commodity ("thing") and performance ("shall the world perceive"): "Presume not that I am the thing I was, / For God doth know, so shall the world perceive, / That I have turned away my former self; / So will I lose those who kept me company" (5.5.54-57). Within the Henriad, Sandra Fischer observes, characters "habitually appropriate economic language [...] to abandon feudalism and to accept a different economic construct of reality".$^{68}$ Here though, Hal's language establishes kingly identity both as part of a framework of commercial exchange and a drama of prostitution, "a metaphor for the behaviour of those historical figures in the play for whom selling themselves or 
screwing others, had become a political fact of life" ${ }^{69}$ Commodity in the Henriad is thus "admirable in the way it maximizes circulation", ${ }^{70}$ especially in its capacity to interweave the factors of identity and gender inherent to market interests that honour the prostitute as much as the prince. The play, itself an object of trade, particularly appropriates official systems of meaning to give a new, more positive image of characters such as Quickly and subvert the superiority and abuse of power of her clients, such as Falstaff, or the future king, Prince Hal.

\section{Commodity appropriating its own agency}

The introductory relation between Quickly's performance and commodity leads us on to what may seem, at first glance, to be a more tenuous link between two of Shakespeare's other women characters. If a relative treatment of women as exchange objects in both the Henriad and Pericles has been given little scholarly attention, this is probably because academics have seen the subject matter of the Romances as too far removed from the prosaic Southwark tavern. Steven Mullaney in The Place of the Stage: License, Play, and Power in Renaissance England (1988) develops connections between Marina's "performance" and the player/prostitute with the idea that reproducing the dominant dynamics of a given culture does not necessarily reinforce those dynamics. ${ }^{71}$ More recently, however, scholars such as Gordon McMullan have taken a broader view of the Romance pattern as a "detached hieratic stance [...] beyond the quotidian world [...] a point of access to essence, a way to move beyond actuality to archetype", ${ }^{72}$ suggesting that the genre disregards or completely transcends historical or contemporaneous considerations.

Although over a decade separates the creation of the Henry IV plays and Pericles, similarities of treatment solicit agreement that people considered as commodity be allowed a place in society as individuals in both nonetheless. This is especially true in the plays' respective brothel scenes (2.4 and 19) with regards to the characters of Falstaff's mistress, Doll Tearsheet, "Shakespeare's only character to call herself a 'whore' without disowning the term", ${ }^{73}$ whom Quickly has Falstaff first meet at supper (2 Henry IV, 2.1.48-49) and Marina, the daughter of Pericles, Prince of Tyre, who is abducted by pirates and trafficked to the proprietors of a bawdy house. The connections involve how the characters speak, act and how they are represented.

Doll Tearsheet is presented to audiences, as Quickly, with her name as an efficient pointer to her profession. "Doll", notes Jean E. Howard, was a common term for prostitute and "Tearsheet", moreover, "graphically suggests one consequence of unrestrained fornication". ${ }^{74}$ As Helge Kökeritz has pointed out, however, "tear sheet" was also in common use in the sixteenth century as in the sense "sheet of the best quality", ${ }^{75}$ suggesting she may have been exclusive merchandise. This is confirmed since her commerce proves more rewarding than Quickly's; mention is made, for instance, of her buying costly items such as a starched "ruff" $(2.4 .113,120)$, which was an anachronistic reference, since the plays were situated during the Hundred Years' War (1337-1453), to a costly clothing accessory of the Elizabethan period.

In the later play, Marina is also a luxurious item. Dionyza, wife to Cleon, resolves to have the now beautiful woman Pericles entrusted her with as a baby in Tharsus (scene 13) executed by Leonine. The order is given not only out of envy but also to augment Dionyza's daughter's chances of a profitable marriage (scene 15). The Chorus embodied 
by the character of the poet John Gower (c. 1325-1408), whose Confessio amantis (1390-1393) Shakespeare drew upon to write the play, accordingly expresses the reasons for Dionyza's jealousy in terms of financial responsibility and payback: "Marina gets / All praises which are paid as debts, / and not as given" (15.33-35). Further, like Doll's consumer activities, Marina's capture and peddling as a prostitute is grounded in fact. Wallace Shugg explains how: "If the wives or daughters of needy citizens would not be corrupted, the procuress would meet the carriers who brought young innocent girls to London looking for work" ${ }^{76}$ and bawds would send enrollers out into the countryside to pressgang new sex workers. This is probably why, in scene 16 of Pericles, the Pander, and his wife, the Bawd, discuss female commodity in terms of commercial coercion. Their current stock of three venereal disease-ridden prostitutes are insufficient to make a decent living from (16.6-7); their raising of eleven bastards-and bringing them to prostitution when they turned eleven-has also proved an inadequate market strategy (16.12-14). Consequently, when their servant, Boult, purchases Marina from pirates (16.45), the Bawd expresses her intention to obtain the maximum return by putting Marina's maidenhead up for sale to the highest bidder:

BAWD Boult, take you the marks of her, the colour of her hair, complexion, height, age, with warrant of her virginity; and cry 'He that will give most shall have her first.' Such a maidenhead were no cheap thing, if men were as they have been. Get this done as I command you. (Pericles, 16.50-54)

As Suzanne Gossett remarks, as "Marina is an expensive purchase", ${ }^{77}$ the Bawd advises her to obtain gold and good opinion to reimburse the investment: "Mark me, you must seem to do that fearfully which you commit willingly, to despise profit where you have most gain" (16.101-104). Made plain in the Bawd's advice is that the cultural value of innocence can be substituted for money and the opposition traditional morals should offer to this submission is cancelled out by commodity transaction. Nonetheless, the performance of Doll and Marina seems to resist submission and impose self through their command of agency. Doll, for instance, may have been recognisable commodity sitting on Falstaff's knee (2.4.203-252) in dramatisation of Lucas Cranach the Elder's circa 1530 "An ill-matched Pair", an emblematic warning against marketable affection depicting a young girl with an impassive face tickling an ugly old man's beard whilst he smirks lewdly and holds out a necklace in his right hand to recompense her services, ${ }^{78}$ yet her adeptness in managing dissolute customers such as the blustering Pistol, a "cutpurse rascal [...] filthy bung" (2.4.107), or the more worthwhile flattering of Falstaff: "I kiss thee with a constant heart [...] I love thee better than I love e'er a scurvy young boy of them all" (2.4.241-245) means her language has value; it both compromises physical danger (Pistol) and appoints lucrative custom (Falstaff).

Similarly, if one of the fundamental issues in Pericles is a "blurring of gifts and trade [that] is particularly evident where women are involved", ${ }^{79}$ Marina manages never to go as far as the "sexual slippage between giving and selling"; 80 the town governor Lysimachus's cash and admiration is given to Boult without loss of maidenhead: "Proclaim that I can sing, weave, sew, and dance, / With other virtues, which I'll keep from boast, / And I will undertake all these to teach" (19.194-196). If the princess associates herself with prostitutes, seen as objects of entertainment ("sing", "dance") and who also often worked part-time as seamstresses ${ }^{81}$ as Quickly's unintentionally lewd comments in Henry $V$ indicate-"for we cannot lodge and board a dozen or fourteen gentlewomen that live honestly by the prick of their needles, but it will be thought we keep a bawdy house straight" (2.1.28-31), Marina defies commodification by 
pointedly naming activities associated with prostitution without ever prostituting herself. She thus upsets classification as commodity by designating herself as part of a group her staged words intend to fight. Besides, that a boy actor would have performed the princess challenges the early modern logic of both gender and identity; the actor and the character thus doubly transgress their authorised station and refuse attempts to contain their identity as commodity.

\section{Conserving agency beyond containment}

The capacity of the player-as-prostitute to enable audiences to visualise early modern empowerment, through the consumption of the visual commodity of plays, continues even when agency seems definitively contained. Outside the tavern at the end of 2 Henry IV, for instance, Doll's language still challenges endeavours to stifle her agency. She attempts avoiding punishment for involvement in the murder of the tavern customer by claiming she is pregnant and demanding the parish officers for clemency until she gives birth, as was permitted in early modern law ${ }^{82}$-"I'll tell thee what, thou damned tripe-visaged rascal, an the child I go with do miscarry, thou wert better thou hadst struck thy mother" (5. 4. 7-10). Ostensibly her plan does "miscarry" because she is simply disposed of; in Pistol's terms, she is removed "in base durance and contagious prison" (5.5.32).

31 In Henry V, Pistol, who has now married Quickly, mentions Doll's death from venereal disease and her life as a whore. He also gives a reference, through association with Cressida (the unfaithful lover of Troilus in classical legend and a traditional symbol of female inconstancy, who by the early modern period, was held to suffer from leprosy for her unfaithfulness) ${ }^{83}$ to an overriding conception of prostitutes as unhealthy predators. As "lazar" meant leprous and "kite" signified both bird of prey and prostitute $^{84}$ he logically says: "No, to the spital go, / And from the powd'ring tub of infamy / Fetch forth the lazar kite of Cressid's kind, / Doll Tearsheet" (2.1.67-70). The connection between two closed-in contexts, brothel and prison, clearly suggests whores must be contained to ensure the absolute submission of the prostitute's body to socially endorsed consumption. In early modern England, after 1553, prostitutes were sent to the prison known as Bridewell (a former royal palace given by Edward VI to the city) to dissuade, punish and set them to work in an attempt to make them useful to society.

However, while the geographically positioned house of correction had replaced London's houses of ill repute, the suppression of brothels and the creation of institutions did nothing to diminish prostitution. Even deporting prostitutes from Bridewell to Virginia, as of 1618 , to supposedly prevent the propagation of syphilis and reassure the local community, failed to reduce their influence. ${ }^{85}$ Audiences would have, moreover, perhaps understood the significant irony of placing dissolute prostitutes in former royal palaces or deporting them to colonies named after the "Virgin Queen" for society's protection. Further, as Shakespeare positions Quickly and Tearsheet's arrest and removal from the streets of London just after the coronation of Henry V, he points to wider notions pertaining to "familiar metaphors of the well-ordered body or the patriarchal family" 86 in connection with the whole country. Indeed, the powerful matriarch, like the prostitute, is a symbol of potential disorder in the Henriad, whose opening lines pointedly establish England as the personification of a cannibalistic mother state: "No more the thirsty entrance of this soil / Shall daub her lips with her 
own children's blood" (1 Henry IV, 1.1.5-6). Both seem subdued at the same time as Prince Hal's coronation yet the prince's close physical and linguistic proximity to Falstaff, the Stews and his self-professed propensity for the acting profession belie a clear distinction between the prince and the prostitute, even when the latter has been confined to prison and thus contained. The result is that the state is deprived of its conventional glorification but that the whore is honoured, both as a victim and as a person in her own right.

Shakespeare treats Marina in a similar manner. Spectators would have perceived her exemption from commerce in the Mytilene brothel as increasing her marital value as a virtuous bride. Nonetheless, the structure of the Pander and his wife, the bawd, dealing their surrogate daughter parallels that of the early modern family unit aiming to marry their daughter, which suggests that the traditional marriage market was as degrading. As Jeanie Grant More remarks: "Marina's virginity is the commodity that brings a high price on either market, prostitution or marriage" ${ }^{87}$ Lysimachus anticipates the sale in his bid to tempt her to prostitution: "A piece of gold for thy virginity; / Here's twenty to relieve thine honesty" (19.126-26). Later, in the recognition scene, Pericles identifies Marina in terms of precious ornaments ("jewel-like") and emphasises the commerce in his daughter through association with Marina's mother who would have similarly been sold by dowry into marriage ("cased as richly"): "My dearest wife was like this maid, and such / My daughter might have been [...] Her stature to an inch, as wand-like straight, / As silver-voiced, her eyes as jewel-like, / And cased as richly" (21.95-99). Likewise, Marina's father promises her to Lysimachus in financial terms, if it is accepted that there is wordplay on "noble", a coin "worth 6s. 8d. (a third of a pound and half a mark) and the principle high-value coin from 1351 to 1464" 8 : "You shall prevail, were it to woo my daughter, / For it seems you have been noble towards her" (21.245-6). Shakespeare shows how, if the practice was merely a continuation of patriarchal domination from the medieval era, Marina's negotiation can be perceived as particularly commercial because immediately following the brothel episode. It thus reinforces ideas of male abuse of power and highlights the callous gender politics of the early modern period.

Moreover, as Lysimachus's true character is exposed in the plot as a disreputable frequenter of brothels and a fortune-hunter, his capacities as administrator, both of his household and as governor of Mytilene are clearly called into question on a moral basis. The future bridegroom considers Marina as "unworthy of him until he knows she is a princess [21.56-68]"; he only seems "noble" when he really is "shallow, if not opportunistic". ${ }^{89}$ For that reason, if Lysimachus and Pericles figure Marina as a mere object, their contempt for her as a person does nothing to encourage audience sympathy to their cause. On the contrary, just as Nell's autonomy is only superficially bound as she transfers from tavern to prison, Marina's dependence is disputable because the nobility of those in control is clearly dishonoured, either in the closed space of the whorehouse or the confines of the household. More widely, analysis of the unprincipled Lysimachus uncannily resembles A. R. Braunmuller's of Hal's character - "realpolitik and the immoral arrogance of deadly choplogic"90-to suggest that Shakespeare's sympathy goes to characters usually visualised as "commodities", whether this be in the Henriad, traditionally held to concern historical and governmental considerations, or in plays such as Pericles, considered today to contribute to the Romance genre. 


\section{Conclusion}

PANDER O, our credit comes not in like the commodity, nor the commodity wages not with the danger. (Pericles, 16.26-27)

Eric Partridge's etymological reading of "commodity" here as a slang derivative of "the female pudend" 91 encapsulates Shakespeare's show of consumer society in the Henriad and in Pericles. The Pander's choice of vocabulary pointing to merchandise ("commodity") in exchange for capital ("credit" and "wages") could also denote the consumption of the visual commodities of plays and the performance of players in them. As we have seen, both undercut the control afforded to the consumer by according the power of transformation to the object: Quickly decrees her own rights as a consumer, imposes a prostitute's point of view and, when viewed as part of a diptych, presents a moralising complement that illuminates Falstaff or Hal's discreditable conduct. Doll is a simple prostitute, the most banal of characters, yet thanks to Shakespeare's choice of her name, the language she uses, and her performance in the situations she is placed in, is allowed to become somebody in her own right. Even when Boult lasciviously declares "Performance shall follow" (19.49) after buying Marina from pirates to prostitute her Shakespeare's equivocal treatment of her provides the necessary space through which to understand attitudes towards "commodity" in early modern society.

If Ben Jonson, in his Ode to Himself (1629), referred to Pericles as a "mouldy tale" ${ }^{92}$ and Doll is arrested by callous watchmen and expires, the endings also deny official forms of domination because the prostitute is unjustly put in prison and the loquacious princess is silenced into marriage by an unscrupulous suitor. If keeping early modern order intact necessarily implied a certain vision of commodity consumption, visualising consumer society through the lens of the commodity of the play in Shakespeare's theatre has suggested a more complex early modern social interaction. The works studied here have raised the issue of a migration of identities through performance allowing for a development of notions of consumerism that give credit to differing concepts of commodity: the reevaluation of woman as an exchange good or a symbol of isolation to consider the early modern prostitute's role as a value broker with the potential to disrupt traditional societal norms. Indeed, commodity, usually thought of in terms of object only, is also a privileged space within which to shape the self. In this way, at least on Shakespeare's stage, the new commodity market can potentially be seen to favour the development of the self by challenging traditional abuses of (male) power that have here been represented by the brothel scenes in Henry IV and Pericles.

\section{BIBLIOGRAPHY}

Bailey, Amanda, of Bondage: Debt, Property, and Personhood in Early Modern England. Philadelphia: University of Pennsylvania Press, 2013. 
Bailey, Amanda, “Timon of Athens, Forms of Payback, and the Genre of Debt." English Literary Renaissance 41 (2011): 375-400.

Bailey, Derrick Sherwin. Sexual Relation in Christian Thought. New York: Harper, 1959.

Beckermann, Bernard. Shakespeare at the Globe 1599-1609. New York: Collier Macmillan, 1962.

Beier, A. L. Masterless Men. London: Methuen, 1984.

Berry, Herbert and William, Ingram. English Professional Theatre, 1530-1660, edited by Glynne Wickham. Cambridge: Cambridge University Press, 2000.

Bradley, Simon and Nikolaus, Pevsner. London 1: The City of London. New Haven: Yale University Press, 1997.

Braunmuller, A. R. "Henry IV, Part 2: A modern Perspective." In Shakespeare, William. Henry IV, Part 2. Ed. Barbara A. Mowat and Paul Werstine, 303-321. New York: Washington Square Press, 1999.

Briggs, Julia. This Stage-Play World: Texts and Contexts, 1580-1625. Oxford: Oxford University Press, [1983] 1997.

Burford, E. J. Bawds and Lodgings: A History of the London Bankside Brothels, c.100-1675. London: Peter Owen, 1976.

Cook, Barrie. Angels and Ducats: Shakespeare's Money \& Medals. London: British Museum Press, 2012. Cranach the Elder, Lucas. “An ill-matched Couple.” Museum Kunstpalast, Düsseldorf. http:// www.lucascranach.org/digitalarchive.php/DE_SMKP_M2248.

Crowley, Robert. One and thyrtye epigrammes wherein are brieflye touched so manye abuses, that maye and ought to be put away. London: Robert Crowley, 1550.

Dabhoiwala, Faramerz. "The Pattern of Sexual Immorality in Seventeenth and Eighteenth Century London." In Londonopolis: Essays in the Cultural and Social History of Early Modern London, edited by Paul Griffiths and Mark S. R. Jenner, 86-106. Manchester: Manchester University Press, 2000.

De Grazia, Margareta. “The ideology of superfluous things: King Lear as a period piece." In Subject and Object in Renaissance Culture, edited by Margareta de Grazia, Maureen Quilligan and Peter Stallybrass, 17-43. Cambridge: Cambridge University Press, 1996.

Dobson, Michael and Stanley Wells, eds. The Oxford Companion to Shakespeare. Oxford: Oxford University Press, 2001.

Dutton, Richard. Mastering the Revels. The Regulation and Censorship of English renaissance Drama. Iowa City: University of Iowa Press, 1991.

E[dgar], T[homas]. The Lavves Resolutions of Womens Rights. London: John More, 1632.

Fischer, Sandra K. “'He means to pay': Value and Metaphor in the Lancastrian Tetralogy.” In Shakespeare's Histories, edited by Emma Smith, 123-142. Oxford: Blackwell Publishing Ltd. 2004.

Fouassier-Tate, Frédérique. "Fact versus Fiction: The Construction of the Figure of the Prostitute in Early Modern England, Official and Popular Discourses." In Female Transgression in Early Modern Britain: Literary and Historical, edited by Richard Hillman and Pauline Ruberry-Blanc, 71-91. Farnham: Ashgate Publishing Limited, 2014.

Greene, Robert. A notable discouery of coosenage Now daily practised by sundry lewd persons, called connie-catchers, and crosse-byters. Plainely laying open those pernicious sleightes that hath brought many 
ignorant men to confusion. ... With a delightfull discourse of the coosenage of colliers. London: Iohn Wolfe for T. N[elson], 1592.

Grose, Francis. A Classical Dictionary of the Vulgar Tongue. London: Hooper and Co, 1796.

Gurr, Andrew. Playgoing in Shakespeare's London. Cambridge: Cambridge University Press. [1987] 2005.

Gurr, Andrew. The Shakespearean Stage: 1574-1642. Cambridge: Cambridge University Press, [1992] 2009.

Gurr, Andrew. Shakespeare's Workplace: Essays on Shakespearean Theatre. Cambridge: Cambridge University Press, 2017.

Gurr, Andrew and Mariko Ichikawa. Staging in Shakespeare's Theatres. Oxford: Oxford University Press, 2011.

Goodman, Nan. Banished: Common Law and the Rhetoric of Social Exclusion in Early New England. Philadelphia: University of Pennsylvania Press, 2012.

Haselkorn, Anne A. Prostitution in Elizabethan and Jacobean Comedy. New York: Whitson, 1983.

Hillman, Richard. "Criminalizing the Woman's Incest: Pericles and its Analogues." Female Transgression in Early Modern Britain: Literary and Historical Explorations, edited by Richard Hillman and Pauline Ruberry-Blanc, 15-29. Farnham: Ashgate Publishing Limited, 2014.

Howard, Jean E. "Crossdressing, The Theatre, and Gender Struggle in Early Modern England." Shakespeare Quarterly 39 (1988): 418-440.

Howard, Jean E. The Stage and Social Struggle in Early Modern England. New York: Routledge, 1994.

Hughes, P. L. and J. F. Larkin, eds. Tudor Royal Proclamations. New Haven: Yale University Press, 1964.

Kökeritz, Helge. “Punning Names in Shakespeare.” Modern Language Notes 65 (1950): 240-243.

Knowles, James, ed. The Roaring Girl and Other City Comedies. Oxford: Oxford University Press, 2001. Kussmaul, Ann. Servants in Husbandry in Early Modern England. Cambridge: Cambridge University Press, 1981.

Lenz, Joseph. “Base Trade: Theater as Prostitution.” English Literary History 60 (1993): 833-855.

Lipson, Ephriam. The Economic History of England. London: Adam \& Charles Black, [1915] 1956.

McMullan, Gordon. Shakespeare and the Idea of Late Writing. Cambridge: Cambridge University Press, 2007.

Mendelsen, Sarah and Patricia Crawford. Women in Early Modern England, 1550-1720. Oxford: Oxford University Press, 1998.

More, Jeanie Grant. “Riddled Romance: Kingship and Kinship in 'Pericles'." Rocky Mountain Review of Language and Literature 1 (2003): 33-48.

Muir, Kenneth. The Sources of Shakespeare's Plays. Oxon: Routledge, [1977] 2009.

Mullaney, Steven. The Place of the Stage: License, Play, and Power in Renaissance England. Ann Arbor: University of Michigan Press, [1988] 1995.

Palliser, David, Michael. The Age of Elizabeth, England Under the Later Tudors, 1547-1603. Harlow: Longman, [1983] 1992. 
Partridge, Eric. A Dictionary of the Underworld: British and American. Oxon and New York: Routledge, [1949] 2015.

Pound, John. Poverty and Vagrancy in Tudor England. Harlow: Longman, 1971.

Randall, Keith. Henry VIII and the Reformation in England. Abingdon: Hodder Murray, [2001] 2005.

Rosenthal, Laura J. “The Whore's Estate: Sally Salisbury, Prostitution, and Property in

Eighteenth-Century London." In Women, Property, and the Letters of the Law in Early Modern England, edited by Andrew Buck and Margaret W. Ferguson, 95-121. Toronto: University of Toronto Press, 2004.

Salgado, Gamini. The Elizabethan Underworld. London: J. M. Dent, 1977.

Salkeld, Duncan. Shakespeare Among the Courtesans. Abingdon: Routledge, [2012] 2016.

Salusbury, G. T. Street Life in Medieval England. Oxford: Pen-In-Hand, 1948.

Scolnicov, Hanna. Woman's Theatrical Space. Cambridge: Cambridge University Press, 1994.

Sharpe, J. A. Crime in Early Modern England 1550-1750. London: Longman, 1984.

Shugg, Wallace. “Prostitution in Shakespeare’s London.” Shakespeare Studies 10 (1977): 291-313.

Shakespeare, William. King Henry IV, Part 1. Edited by David Scott Kastan. The Arden Shakespeare. London: Thomson Learning, 2002.

Shakespeare, William. King Henry IV, Part 2. Edited by James C. Bulman. The Arden Shakespeare. London: Bloomsbury Publishing, 2016.

Shakespeare, William. 2 Henry IV. Edited by Stephen Greenblatt, Walter Cohen, Jean E. Howard and Katherine Eisaman Maus. The Norton Shakespeare. New York: W. W. Norton \& Company, [1997] 2008.

Shakespeare, William. Henry V. Edited by Jonathan Bate and Eric Rasmussen. The RSC Shakespeare. Basingstoke: Macmillan, 2010.

Shakespeare, William. Pericles. Edited by Suzanne Gossett. The Arden Shakespeare. London: Thompson Learning, 2004.

Smith, Preserved. “Some Old Blue-Laws.” The Open Court 4 (1915): 193-208.

Smith, Preserved. The Age of Reformation. New York: Henry Holt, 1920.

“Stew." Oxford English Dictionary, http://www.oed.com/ (accessed March 3, 2015).

Stow, John. A suruay of London Contayning the originall, antiquity, increase, moderne estate, and description of that citie. London: John Windet, 1598.

Streitman, Krisztina, N. "William Kemp and Falstaff: Reality and Role in Elizabethan Popular Culture." In Early Modern Communi(cati)ons: Studies in early Modern Literature and Culture, edited by Kinga Földváry and Erszébet Stróbl, 152-177. Newcastle upon Tyne: Cambridge Scholars Publishing, 2012.

Stubbes, Phillip. The anatomie of abuses [...]. Verie godly to be read of all true Christians euery where, but most chiefly, to bee regarded in England. London: Richard Jones, 1595.

Thomas, Thomas. Dictionarium linguae Latinae et Anglicanae In hoc opere quid sit praestitum, \& ad superiores lexikographos adiectum, docebit epistola ad lectorem. London: Richard Boyle, 1587. 
Walker, Gilbert. A manifest detection of the moste vyle and detestable vse of diceplay, and other practises lyke the same a myrrour very necessary for all yonge gentilmen [and] others sodenly enabled by worldly abu[n]dace [sic], to loke in. Newly set forth for their behoufe. London: Abraham Vele, 1555.

Whetstone, George. A mirour for magestrates of cyties [...]. And hereunto, is added, A touchstone for the time: containyng: many perillous mischiefes, bred in the bowels of the citie of London: by the infection of some of thease sanctuaries of iniquitie. London: Richarde Jones, 1584.

\section{ENDNOTES}

1. O.E.D. "stew". http://www.oed.com/ (accessed January 2 2016).

2. Jean E. Howard, The Stage and Social Struggle in Early Modern England (New York: Routledge, 1994), 43.

3. Jean E. Howard, "Crossdressing, The Theatre, and Gender Struggle in Early Modern England, "Shakespeare Quarterly 39, (1988): 440.

4. See especially, Anne A. Haselkorn, Prostitution in Elizabethan and Jacobean Comedy (New York: Whitson, 1983) and Nan Goodman, Banished: Common Law and the Rhetoric of Social Exclusion in Early New England (Philadelphia: University of Pennsylvania Press, 2012).

5. Joseph Lenz, "Base Trade: Theater as Prostitution," English Literary History 60 (1993).

6. James Knowles, ed., The Roaring Girl and Other City Comedies (Oxford: Oxford University Press, 2001), ix.

7. See especially John Pound, Poverty and Vagrancy in Tudor England (Harlow: Longman, 1971) and A. L. Beier, Masterless Men (London: Methuen, 1984).

8. See especially E. J. Burford, Bawds and Lodgings: A History of the London Bankside Brothels, c. 100-1675 (London: Peter Owen, 1976), Wallace Shugg, "Prostitution in Shakespeare's London," Shakespeare Studies 10 (1977): 291-313 and J. A. Sharpe, Crime in Early Modern England 1550-1750 (London: Longman, 1984).

9. See especially Ann Kussmaul, Servants in Husbandry in Early Modern England (Cambridge: Cambridge University Press, 1981), Bernard Beckermann, Shakespeare at the Globe

Globe

1599-1609 (New York: Collier Macmillan, 1962) and Andrew Gurr and Mariko Ichikawa, Staging in Shakespeare's Theatres (Oxford: Oxford University Press, 2011).

10. Duncan Salkeld, Shakespeare Among the Courtesans (Abingdon: Routledge, [2012] 2016), 135, 166.

11. Gamini Salgado, The Elizabethan Underworld (London. J. M. Dent, 1977), 58.

12. Robert, Greene, A notable discouery of coosenage (London: Iohn Wolfe for T. N[elson], 1592), 4, 2.

13. Eric Partridge, A Dictionary of the Underworld: British and American (Oxon and New York: Routledge, [1949] 2015), 743-744.

14. Greene, A notable discouery of coosenage, 2.

15. Ibid., 4.

16. Sarah Mendelsen and Patricia Crawford, Women in Early Modern England, 1550-1720 (Oxford: Oxford University Press, 1998), 336.

17. Partridge, A Dictionary of the Underworld, 743.

18. Frédérique Fouassier-Tate, "Fact versus Fiction: The Construction of the Figure of the Prostitute in Early Modern England, Official and Popular Discourses," in Female Transgression in Early Modern Britain: Literary and Historical, ed. Richard Hillman and Pauline Ruberry-Blanc (Farnham: Ashgate Publishing Limited, 2014), 87. 
19. Wallace Shugg, "Prostitution in Shakespeare's London," Shakespeare Studies 10 (1977): 292.

20. Derrick Sherwin Bailey, Sexual Relation in Christian Thought (New York: Harper, 1959), 162-163.

21. G. T. Salusbury, Street Life in Medieval England (Oxford: Pen-In-Hand, 1948), 154.

22. Salgado, The Elizabethan Underworld, 52.

23. Simon Bradley and Nikolaus, Pevsner, London 1: The City of London (New Haven: Yale University Press, 1997), 57.

24. Keith Randall, Henry VIII and the Reformation in England (Abingdon: Hodder Murray, [2001] 2005), 63.

25. Ephriam Lipson, The Economic History of England (London: Adam \& Charles Black, [1915] 1956), 410, 421-422.

26. David Michael Palliser, The Age of Elizabeth, England Under the Later Tudors, 1547-1603 (Harlow: Longman, [1983] 1992), 156.

27. John Stow, A suruay of London Contayning the originall, antiquity, increase, moderne estate, and description of that citie (London: John Windet, 1598), 331.

28. Ibid., 332.

29. Shugg, "Prostitution in Shakespeare's London," Shakespeare Studies, 293.

30. Preserved Smith, "Some Old Blue-Laws," The Open Court 4 (1915): 206-207.

31. P. L. Hughes and J. F. Larkin, eds., Tudor Royal Proclamations (New Haven: Yale University Press, 1964), 355-356.

32. Robert Crowley, One and thyrtye epigrammes wherein are brieflye touched so manye abuses, that maye and ought to be put away (London: Robert Crowley, 1550), B ii.

33. Wallace Shugg, "Prostitution in Shakespeare's London," Shakespeare Studies 10 (1977): 306.

34. Faramerz Dabhoiwala, "The Pattern of Sexual Immorality in Seventeenth and Eighteenth Century London," in Londonopolis: Essays in the Cultural and Social History of Early Modern London, ed. Paul Griffiths and Mark S. R. Jenner (Manchester: Manchester University Press, 2000), 106.

35. Thomas Thomas, Dictionarium linguae Latinae et Anglicanae In hoc opere quid sit praestitum, \& ad superiores lexikographos adiectum, docebit epistola ad lectorem (London: Richard Boyle, 1587), Q qq vi.

36. Wallace Shugg, "Prostitution in Shakespeare's London," Shakespeare Studies 10 (1977): 301.

37. George Whetstone, A mirour for magestrates of cities (London: Richarde Jones, 1584), D iii.

38. Ibid.

39. Andrew Gurr, Playgoing in Shakespeare's London (Cambridge: Cambridge University Press. [1987] 2005), 64.

40. Theatres such as The Globe held up to three thousand spectators at any one time. Andrew Gurr and Mariko Ichikawa, Staging in Shakespeare's Theatres (Oxford: Oxford University Press, 2011), 3.

41. For a basic penny fee an apprentice brought as much as Elisabeth I herself could buy. Andrew Gurr, The Shakespearean Stage: 1574-1642 (Cambridge: Cambridge University Press, [1992] 2009), 19.

42. See Krisztina N. Streitman, "William Kemp and Falstaff: Reality and Role in Elizabethan Popular Culture," in Early Modern Communi(cati)ons: Studies in early Modern Literature and Culture, ed. Kinga Földváry and Erszébet Stróbl (Newcastle upon Tyne: Cambridge Scholars Publishing, 2012), 165.

43. Joseph Lenz, "Base Trade: Theater as Prostitution," English Literary History 60 (1993): 833. 
44. Margareta De Grazia, "The ideology of superfluous things: King Lear as a period piece," in Subject and Object in Renaissance Culture, ed. Margareta de Grazia, Maureen Quilligan and Peter Stallybrass (Cambridge: Cambridge University Press, 1996), 18-19.

45. Lenz, "Base Trade: Theater as Prostitution," English Literary History, 835.

46. Gurr, The Shakespearean Stage: 1574-1642, 74.

47. Lenz, "Base Trade: Theater as Prostitution," English Literary History, 836.

48. Gurr and Ichikawa, Staging in Shakespeare's Theatres, 14.

49. Julia Briggs, This Stage-Play World: Texts and Contexts, 1580-1625 (Oxford: Oxford University Press, [1983] 1997), 30.

50. Gurr, Playgoing in Shakespeare's London, 183.

51. Shugg, "Prostitution in Shakespeare's London," Shakespeare Studies, 296.

52. Lenz, "Base Trade: Theater as Prostitution," English Literary History, 838.

53. Amanda Bailey, of Bondage: Debt, Property, and Personhood in Early Modern England (Philadelphia: University of Pennsylvania Press, 2013), 4-5.

54. Bailey, Amanda, "Timon of Athens, Forms of Payback, and the Genre of Debt," English Literary Renaissance 41 (2011): 381.

55. Phillip Stubbes, The anatomie of abuses (London: Richard Jones, 1595), 105.

56. Lenz, "Base Trade: Theater as Prostitution," English Literary History, 840-841.

57. Ibid., 841.

58. Nely Keinänen, private correspondence with the author (September 15, 2017).

59. Herbert Berry and William Ingram, English Professional Theatre, 1530-1660, ed. Glynne Wickham (Cambridge: Cambridge University Press, 2000), 394.

60. Ibid., 221.

61. Andrew Gurr, Shakespeare's Workplace: Essays on Shakespearean Theatre (Cambridge: Cambridge University Press, 2017), 15-16, 22.

62. Michael Dobson and Stanley Wells, eds., The Oxford Companion to Shakespeare (Oxford: Oxford University Press, 2001), 359.

63. William Shakespeare, King Henry IV, Part 1, ed. David Scott Kastan (London: Thomson Learning, 2002), 5.

64. Richard Hillman, "Criminalizing the Woman's Incest: Pericles and its Analogues," in Female Transgression in Early Modern Britain: Literary and Historical Explorations, ed. Richard Hillman and Pauline Ruberry-Blanc Farnham: Ashgate Publishing Limited, 2014), 15.

65. Francis Grose, A Classical Dictionary of the Vulgar Tongue (London: Hooper and Co, 1796), H1.

66. Helge Kökeritz, "Punning Names in Shakespeare," Modern Language Notes 65 (1950): 242.

67. Nely Keinänen, private correspondence with the author (September 15, 2017).

68. Sandra K. Fischer, "'He means to pay': Value and Metaphor in the Lancastrian Tetralogy," in Shakespeare's Histories, ed. by Emma Smith (Oxford: Blackwell Publishing Ltd. 2004), 124.

69. William Shakespeare, King Henry IV, Part 2, ed. James C. Bulman (London: Bloomsbury Publishing, 2016), 75.

70. Laura J. Rosenthal, “The Whore's Estate: Sally Salisbury, Prostitution, and Property in Eighteenth-Century London," in Women, Property, and the Letters of the Law in Early Modern England, ed. Andrew Buck and Margaret W. Ferguson, (Toronto: University of Toronto Press, 2004), 111.

71. Steven Mullaney, The Place of the Stage: License, Play, and Power in Renaissance England (Ann Arbor: University of Michigan Press, [1988] 1995), 132.

72. Gordon McMullan, Shakespeare and the Idea of Late Writing (Cambridge: Cambridge University Press, 2007), 31.

73. Dobson and Wells, The Oxford Companion to Shakespeare, 359. 
74. William Shakespeare, 2 Henry IV, ed. Stephen Greenblatt, Jean E. Howard et. al. (New York: W. W. Norton \& Company, [1997] 2008), 1351, 1321.

75. Helge Kökeritz, "Punning Names in Shakespeare," Modern Language Notes, 243.

76. Shugg, "Prostitution in Shakespeare's London," Shakespeare Studies, 296.

77. William Shakespeare, Pericles, ed. Suzanne Gossett (London: Thompson Learning, 2004), 327.

78. Lucas Cranach the Elder, "An ill-matched Couple," http://www.lucascranach.org/ digitalarchive.php/DE_SMKP_M2248. (accessed July 4 2016).

79. Shakespeare, Pericles, ed. Susanne Gossett, 327.

80. Ibid., 150.

81. Dobson and Wells, The Oxford Companion to Shakespeare, 359.

82. T[homas] E[dgar], The Lavves Resolutions of Womens Rights (London: John More, 1632), 207.

83. Kenneth Muir, The Sources of Shakespeare's Plays (Oxon: Routledge, [1977] 2009), 141.

84. William Shakespeare, Henry $V$, ed. Jonathan Bate and Eric Rasmussen (Basingstoke: Macmillan, 2010), 43.

85. Fouassier-Tate, "Fact versus Fiction," 83.

86. Shakespeare, King Henry IV, Part 1, ed. David Scott Kastan, 41.

87. Jeanie Grant More, "Riddled Romance: Kingship and Kinship in 'Pericles'," Rocky Mountain Review of Language and Literature 1 (2003): 41.

88. Barrie Cook, Angels and Ducats: Shakespeare's Money \& Medals (London: British Museum Press, 2012), 39.

89. More, "Riddled Romance: Kingship and Kinship in 'Pericles'," Rocky Mountain Review of Language and Literature, 42.

90. A. R. Braunmuller, "Henry IV, Part 2: A modern Perspective," in William Shakespeare, Henry IV, Part 2, ed. Barbara A. Mowat and Paul Werstine (New York: Washington Square Press, 1999), 307.

91. Partridge, A Dictionary of the Underworld, 142.

92. Dobson and Wells, The Oxford Companion to Shakespeare, 344.

\section{ABSTRACTS}

In this account of early modern prostitution and Shakespeare's theatre, with its direct representation of brothel activities, I reconsider the extensively discussed idea of women as "commodity", meaning a symbol of abjection to consider the early modern prostitute's role as a value broker. I claim that prostitutes commanded the potential to transfer, perturb, and shape social norms more than they have been given credit for and that Shakespeare's plays' reworkings of the notion of female characters as exchange goods could have the effect of making another voice heard-that of agency. I examine "commodity" on Shakespeare's stage, in particular representations of women as objects in the tavern and brothel scenes in the visual commodities of 1 and 2 Henry IV (1596-1597, 1597-1598) and Pericles (1608) that show women to be subservient, sold for money and yet showcased to expose the illusion of this control.

INDEX

Keywords: Shakespeare, commodities, spectacle, containment, empowerment 


\section{AUTHOR}

\section{STEPHANIE MERCIER}

Stephanie Mercier is an agrégée in English. She teaches preparatory courses for business school and the Sciences Politiques entrance exams, classes in English applied to business, marketing, economics, insurance, theatre and cinema. She has obtained a B. A. Honours in French and Economics, a Master's Degree in English and is currently a PhD candidate at the University of Helsinki under the supervision of Nely Keinänen and Terttu Nevalainen. 